\title{
既存杭利用のための基礎解体方 法の実証実験
}

\section{EXPERIMENT OF DEMOLITION METHOD OF FOUNDATION FOR REUSING EXISTING PILES}

勝二理智

藤森健史

キーワード :

解体, 基礎, 既存杭, 施工性, 杭の弾性波探査試験

Keywords:

Demolition, Foundation, Existing pile, Working efficiency, Pile integrity test
Michito SHOJI — $* 1 \quad$ Takeshi FUJIMORI — * 1

In case of reusing only existing piles other than foundation, it is necessary to select a demolition method of the foundation that doesn't damage the piles. There is no study to examine the relation between the extent of the pile damage and the working efficiency in the demolition method. This paper describes the experiments of the relation using the foundations and the piles of building under demolition. The method with cutter is the most reasonable because its working efficiency is equivalent to the method with crusher and its effect on the pile soundness is equivalent to the method with wire-saw.

\section{1.はじめに}

建物の建替え時に既存杭を利用するにあたり，既存基礎 (地中梁, パイルキャップ) ごと再利用する方がコストダウン効果は大きいが, 設計条件によっては，それら基礎を解体し杭を露出させる必要が生 じる。その場合，杭を損傷させない解体方法を選択する必要がある が，解体方法ごとの杭損傷度と施工性の関係を検証した例はこれま で報告されていなかった。そこで，2 章で示寸解体方法について， どの方法を用いれば杭を損傷させることなく, 効率良く基礎を解体 可能であるか，実建物の基䃈と杭を用いて実証実験を実施した。

また，既存杭利用にあたり，建物解体後調查に先行して解体前に 調查を行う場合もある $\left.{ }^{1)}, 2\right)$ 。杭頭が露出する解体後と露出していな い解体前では，同一の試験 (例えば杭の弾性波探査試験)でも方法は 変わるため得られる結果も異なるが，その差異に関する報告は見当
たらない。本実験では, 杭損傷度の確認のため基礎解体前後に試験 を実施しており，その試験結果の比較も行った。

\section{2. 基礎の解体方法}

検討した解体方法を図 1 および図 2, 使用した解体機材を写真 1

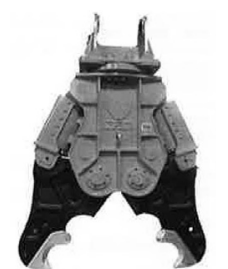

(a) 圧砕機

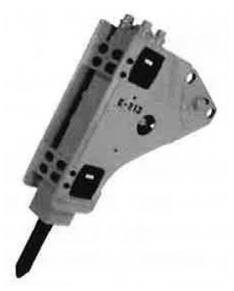

(b) ブレーカ

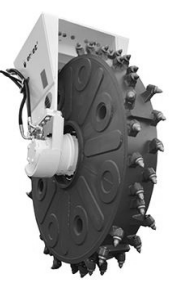

(c) カッター

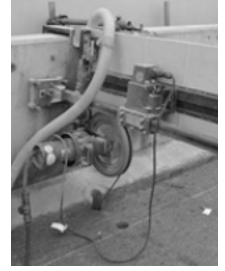

(d) ワイヤーソー
写真 1 使用した解体機材 3), 4), 5)

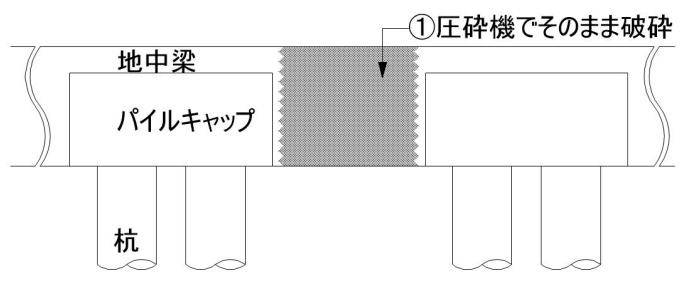

(a) 圧砕解体

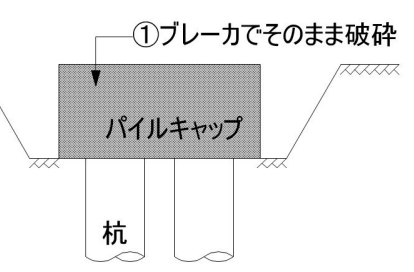

（a）圧砕解体

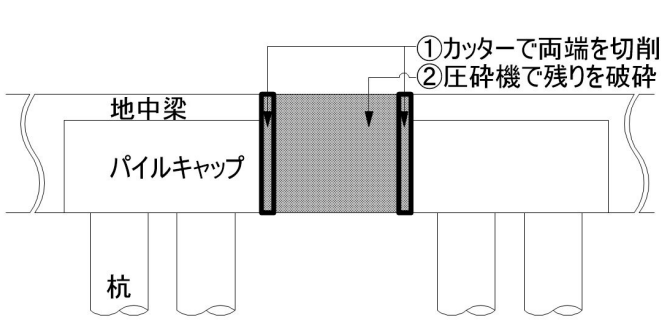

（b）カッター併用解体

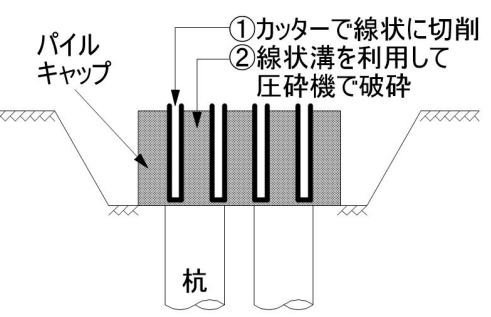

（b）カッター併用解体

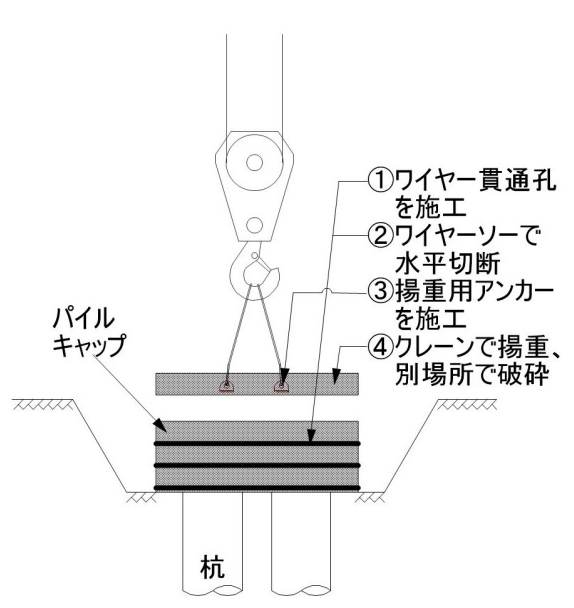

(c) ワイヤーソー併用解体

図 1 検討した地中梁の解体方法

\footnotetext{
(森)大林組技術研究所 博士 (工学)

（～204-8558＼cjkstart東京都清瀬市下清戸 4-640）
}

図 2 検討したパイルキャップの解体方法 
に示す。地中梁については 2 種類, パイルキャップについては 3 種 類の方法の比較検討を実施した。図 1 (a), 図 2 (a) は圧砕機やブレー カ(写真 1 (a) , (b)) を用いる方法で, 最も一般的であり施工性に優れ るが，基礎を破砕する振動が杭に伝わり，杭が損傷する可能性があ る。また, 基䃈だけが壊れるよう加減することは難しく, 誤って杭 まで破砕してしまう可能性もある。図 2(c) はワイヤーソー(写真 1(d))を併用する方法で, 基礎を切断して杭と切り離してから破砕寸 るため, 破砕により杭が損傷する可能性を極めて小さくできる。一 方で， ワイヤーを通す貫通孔の施工や揚重用アンカーの施工，別場 所への揚重移動といった基礎の分割・破砕のための準備作業が多く, 既存杭利用によるコスト・工期のメリットを相殺しかねない。そこ で, 既存杭を損傷させず施工性にも優れる解体方法として, 回転す る車輪にピックが付いたアタッチメント (写真 1 (c) カッター) を併 用寸る方法を考案した。使用したカッターは, 圧砕機やブレーカと 同様に重機に取り付けるアタッチメントで, コンクリートや鉄筋を 切削することが可能であり, 本実験では erkat 社の ERW1000を用い た ${ }^{4)}$ 。図 1(b)の方法では, カッターにより梁両端を垂直に切削し, パイルキャップから切り離した梁を圧砕機やブレーカを用いて破砕 する。この方法によれば, はじめに梁とパイルキャップを切り離す ことで, ワイヤーソーと同様に杭との縁切りを実現でき, その後の 破砕による杭の損傷を回避できる。また, 梁の切削にあたり, ワイ ヤーソーと異なり貫通孔の施工といった準備作業が発生しないため, 作業効率は図 1 (a) 压砕解体とほぼ変わらない。

図 2 (b)の方法では, カッターによりパイルキャップを線状に切削 し, 設けた溝に圧砕機の爪を噛ませて破砕する。パイルキャップが 厚い場合は, カッターの切削深さに合わせて, 前記作業を繰り返す。 この方法によれば, 線状の切削により内部の鉄筋は分断され, パイ ルキャップも小割りになるため, 杭との固着を弱めることができ, ワイヤーソーの縁切りに近い効果を得られる。また, 圧砕機で破砕 できる範囲は切削深さに限定されるため, 図 2 (a) 圧砕解体のように 機材が誤って杭まで達してしまう可能性も極めて小さくなる。なお, 検討したどのパイルキャプの解体方法を用いたとしても, パイルキ ヤップ内に定着していた杭頭鉄筋は曲がったり切断されたりするた め, そのまま再利用するには適さない。新築基礎に接続する際は, その部分を取り除き，新たに鉄筋を継ぐ必要がある。

\section{3. 実証実験方法}

\section{1 実験に用いた基礎と杭}

2 章で示した解体方法について, 実建物の基礎 (地中梁, パイルキ ヤップ) と杭を用いて実験を実施した。実建物は地上 7 階建ての物流 施設 (昭和 48 年竣工) で, 地上部の解体を終えており, 図 3 に示寸配 置で基礎と杭が残っていた。パイルキャップの四方には地中梁が接
合し, パイルキャップ下には杭 3 本が接合している。基礎と杭の諸 元 (寸法, コンクリートの設計基準強度, 配筋仕様) は表 1 の通りで ある。敷地地盤について, 杭支持層は南北に傾斜し, 砂質土と粘性 土が互層となって堆積しており, 地下水位は GL-2m である。

地中梁解体の検討では, パイルキャップに接合する梁 4 本を同一 の方法で解体したのち, パイルキャップがある状態で杭の損傷度を 確認しており，1つの方法につきパイルキャップ 3 基(杭 9 本)で検 討した。パイルキャップ解体の検討では, 接合する梁 4 本を撤去済 みのパイルキャップを解体したのち, 杭の損傷度を確認しており, 1 つの方法につきパイルキャップ 3 基(杭 9 本)で検討した。

\section{2 解体にあたっての管理項目}

地中梁解体について, 図 1 (a)の圧砕解体では, 解体の仕方 (丁寧 か粗雑か)が実駼結果に影響すると考えられたため, 管理項目は特に 設けずに, 杭を再利用しない場合と同等の解体となるよう留意した。 図 3,4で示したように, 地中梁は一部パイルキャップに重なってお り, 図 1 (b) カッター併用解体では, パイルキャップ端部で梁を切削 することとした。パイルキャップ解体について, 図 2 (a) の圧砕解体 では, 地中梁解体時と同様に対応した。図 2 (b) のカッター併用解体 では, 圧砕機で挟み込めるよう $800 \mathrm{~mm}$ の間隔で線状に切削すること とした。図 2 (c) のワイヤーソー併用解体では, 作業効率とクレーン の揚重能力を考慮して, パイルキャップを 4 分割することとした。

\section{3 解体による杭損傷度の確認方法}

杭損傷度を確認するため, 地中梁・パイルキャップの解体前, 地

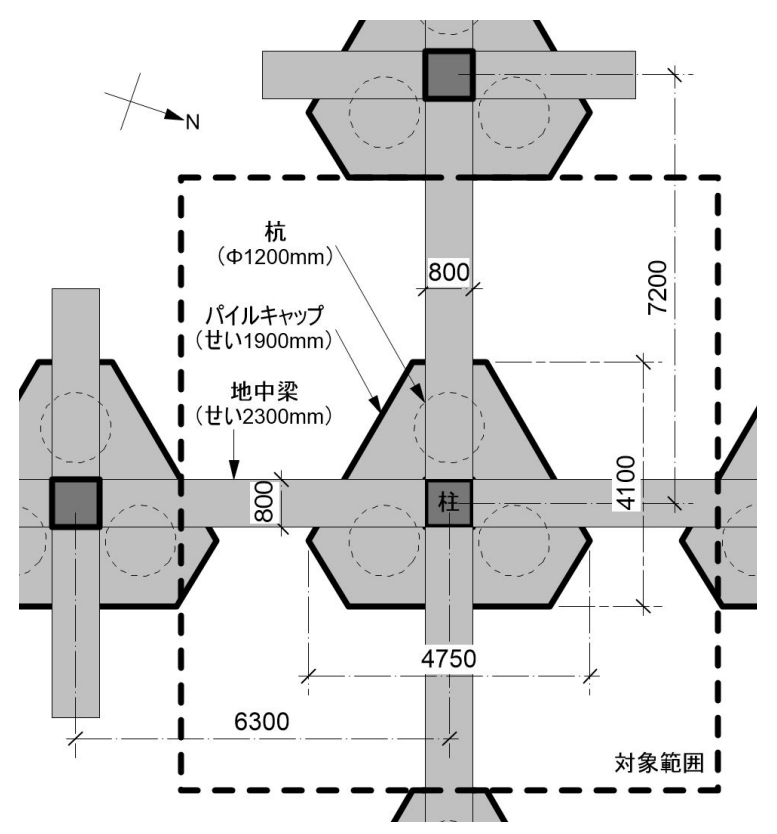

図 3 実験に用いた基礎と杭の配置および寸法

表 1 実験に用いた基礎と杭の諸元

\begin{tabular}{|c|c|c|c|}
\hline 部位 & 寸法 & コンクリート強度 & 配筋仕様 (すべて SD35) \\
\hline 地中梁 & 幅 $800 \mathrm{~mm}$ ，せい $2300 \mathrm{~mm}$ & $210 \mathrm{kgf} / \mathrm{cm}^{2}$ & \begin{tabular}{|l} 
[南北梁] 上端筋 4 5-D29，下端筋 3 4-D29，スターラップ D19@300 \\
[東西梁] 上端筋 4-D29， 下端筋 3-D29，スターラップ D19@300
\end{tabular} \\
\hline パイルキャップ & $\begin{array}{c}\text { 南北 } 4750 \mathrm{~mm}, \text { 東西 } 4100 \mathrm{~mm} \\
\text { せい } 1900 \mathrm{~mm}\end{array}$ & $210 \mathrm{kgf} / \mathrm{cm}^{2}$ & 上端筇 D13@300，下端筋 D22@200 \\
\hline 杭 & 直径 $1200 \mathrm{~mm}$, 杭長 $19 \sim 31 \mathrm{~m}$ & $180 \mathrm{kgf} / \mathrm{cm}^{2}$ & 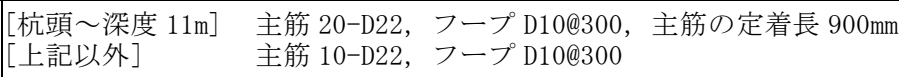 \\
\hline
\end{tabular}


中梁の解体後, パイルキャップの解体後において, 図 4 に示すよう に健全性試験 (表 2 の杭の弾性波探查試験 (IT 試験), 孔内力メラ観 察, 目視観察) を実施した。弾性波探査試験には PROFOUND 社製の IT-system, カメラ観察にはレアックス社製の BIP-0DS200を用いた。

図 4(a) 地中梁・パイルキャップの解体前と図 4(b) 地中梁の解体後 においては, 1 階床スラブから杭頭より $1 \mathrm{~m}$ 深い位置まで鉛直に削孔 して試験孔を形成したのち，杭頭部は孔内カメラ観察，杭地中部は 孔底での弾性波探查試験により, 損傷の度合いと有無を確認した。 この弾性波探査試験においては, ボーリングロッドの先端に取り付 けたビットを用いて孔底を平滑にしたのち，長尺のアルミ管を介し てセンサーを孔底に固定し，同様に挿入した長尺の鋼棒の上端を八 ンマーで打撃しており，1 本の杭に対して再現性のある 4 波を測定 した。図 4(c) パイルキャップの解体後においては, 解体により杭頭 が露出するため, 杭頭部は孔内力メラ観察と外観の目視観察, 杭地 中部は露出した杭頭での弾性波探査試験 (通常の方法, 同様に 4 波測 定)により，損傷の度合いと有無を確認した。

\section{4. 実証実験結果}

\section{1 地中梁解体による杭損傷度}

地中梁の解体前後に実施した健全性試験結果を比較することで, 地中梁の解体方法 (図 1 (a) 圧砕解体, (b) カッター併用解体) による 杭損傷度を評価する。弾性波探査試験で得られた波形を図 5 および 図 6 に示す。どちらの解体方法でも, 試験を実施した杭 9 本すべて で損傷は確認されなかったことから，ここでは，フーチングごとに 代表的な 1 本の結果を示している。図の縦軸は振幅，横軸は打撃入 力した試験孔底からの深度であり, 弾性波の伝播速度は文献 2)上り

\section{表 2 実施した健全性試験}

\begin{tabular}{|c|c|c|}
\hline 番号 & 名称 & 概要 \\
\hline 1 & $\begin{array}{l}\text { 杭の弾性波 } \\
\text { 探查試験 } \\
\text { (IT 試験) }\end{array}$ & 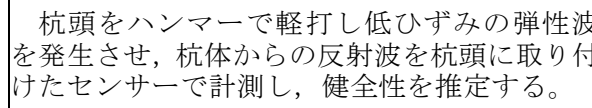 \\
\hline 2 & $\begin{array}{c}\text { 孔内 } \\
\text { カメラ観察 }\end{array}$ & $\begin{array}{l}\text { 杭体に設けた試験孔内にカメラを挿入し, } \\
\text { び割れ等の状況を確認する。 }\end{array}$ \\
\hline 3 & 視 & $\begin{array}{l}\text { 露出した杭頭を直接目視し, ひび害 } \\
\text { 確認する。 }\end{array}$ \\
\hline
\end{tabular}

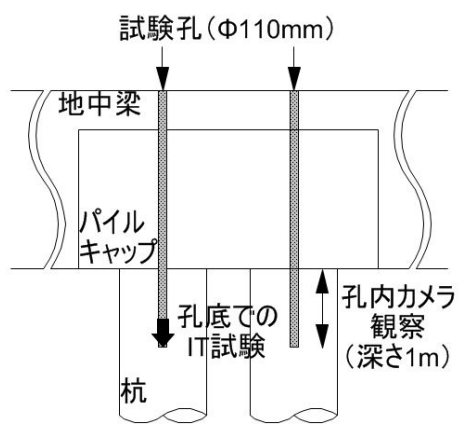

（a）地中梁・パイルキャップの解体前

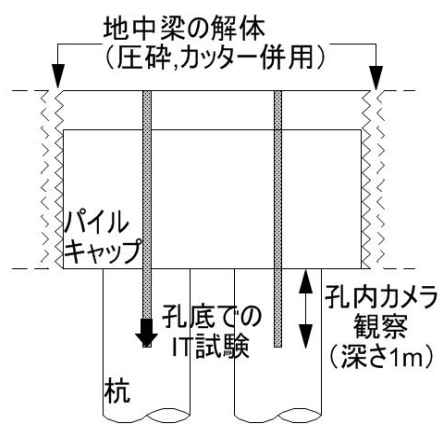

(b) 地中梁の解体後

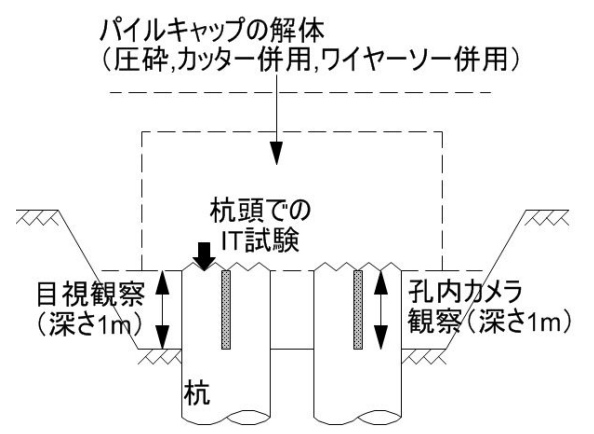

(c) パイルキャップの解体後

\section{図 4 杭損傷度の確認方法}
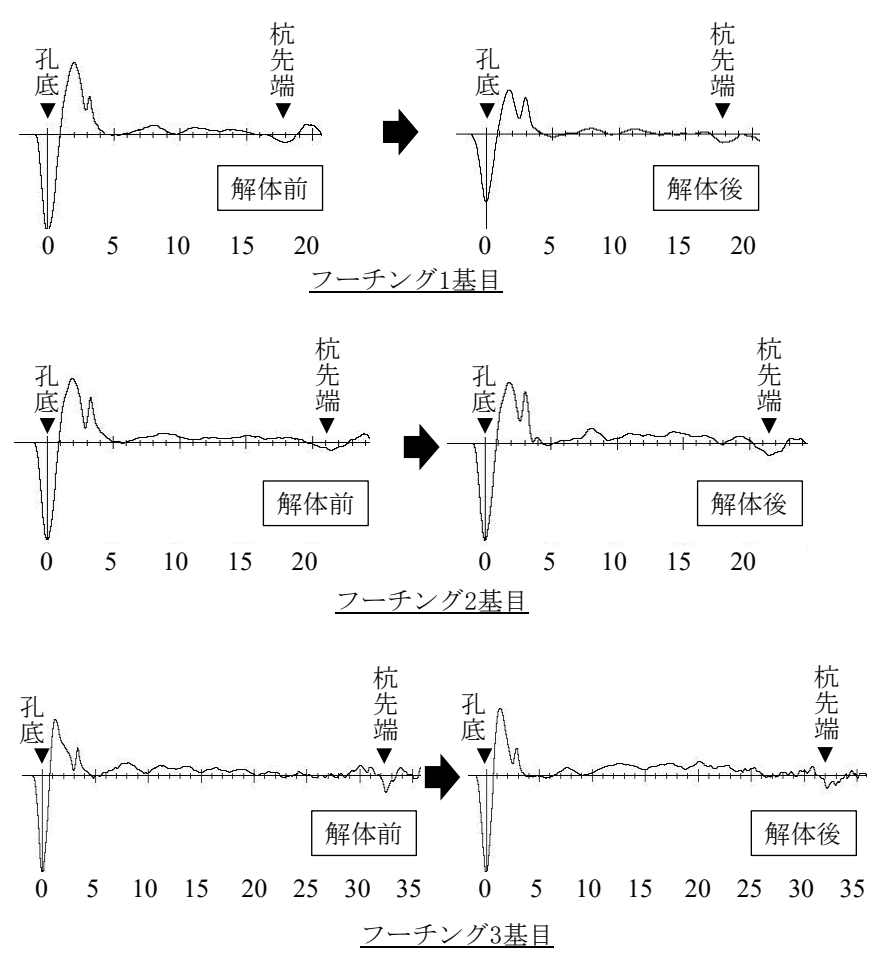

図 5 地中梁の圧砕解体前後の弾性波探査試験波形
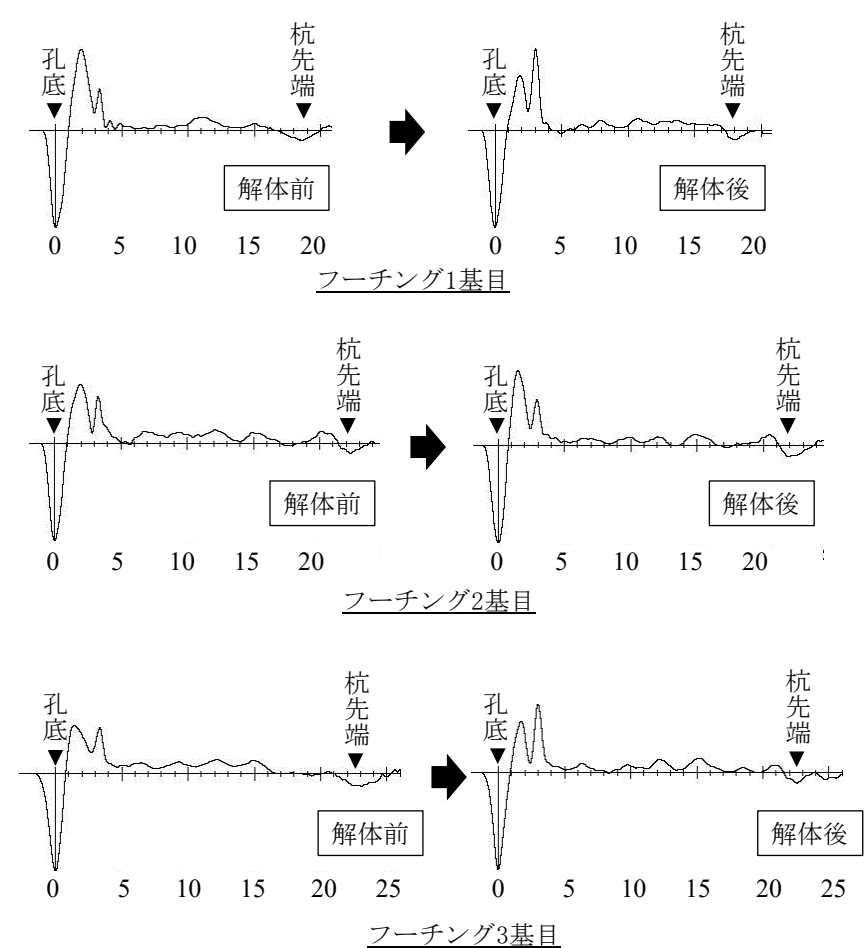

図 6 地中梁のカッター併用解体前後の弾性波探査試験波形 
$3800 \mathrm{~m} / \mathrm{s}$ とした。図 5 および図 6 より, 解体後も解体前と同様に, 杭頭打撃 (深度 $0 \mathrm{~m}$ ) と杭先端反射 (深度 $18 \mathrm{~m}$ ) の振幅が生じ, その間に 下向きに有意な振幅が生じていないことから, 解体により杭地中部 に損傷は生じなかったことを確認できる。

続いて, 孔内カメラ観察結果を図 7 に示寸。図はカッター併用解 体の結果で, 孔内を 360 度撮影した画像を展開し, 杭頭から深度 $1 \mathrm{~m}$ の範囲を示している。図 7 より, 解体後の画像にひび割れは新たに 生じていないことから, 解体により杭頭部には, 杭内部にまで進展 するほどの損傷は生じなかったことを確認できる。また，ここでは 結果を割愛したが，圧砕解体の場合も同様に損傷は生じなかった。 以上より, 考案したカッター併用解体は, 圧砕解体と比較して既存 杭の健全性への影響は同等であり, どちらの方法も杭を損傷させる 可能性は低いと考えられる。

\section{2 パイルキャップ解体による杭損傷度}

パイルキャップの解体前後に実施した健全性試験結果を比較する ことで, パイルキャップの解体方法 (図 2 (a) 圧砕解体, (b) カッター 併用解体，（c）ワイヤーソー併用解体）による杭損傷度を評価する。 まず, 圧砕解体について, 弾性波探查試験で得られた波形を図 8 お
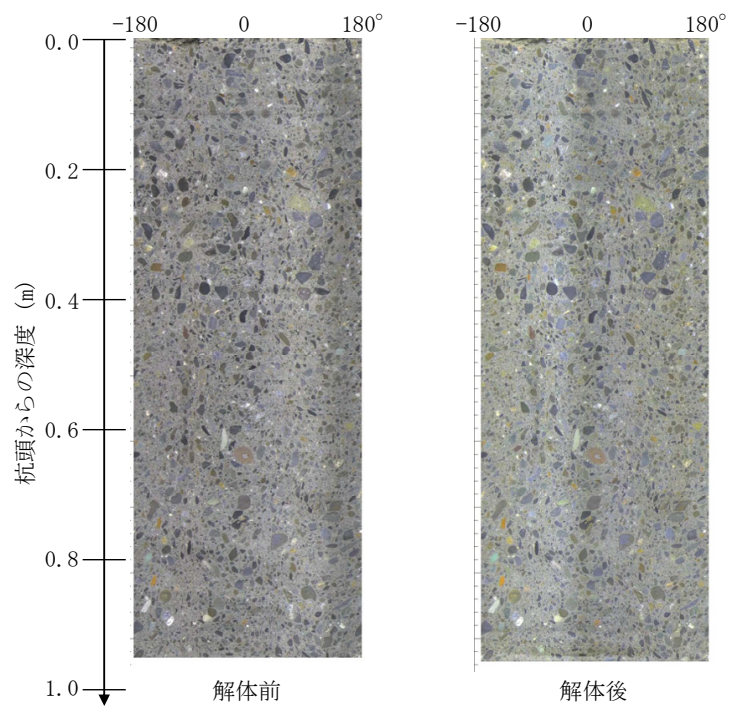

図 7 地中梁のカッター併用解体前後の孔内カメラ観察結果

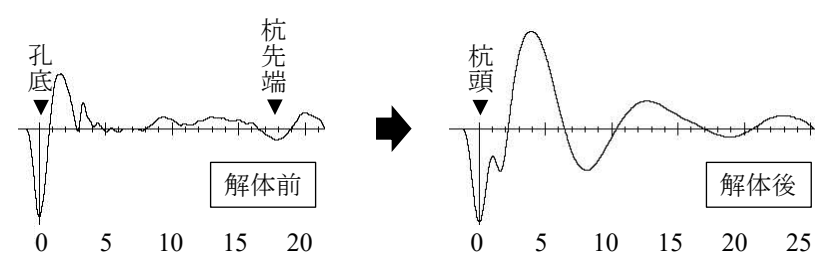

図 8 パイルキャップの圧砕解体前後の

弾性波探査試験波形(損傷が生じた杭)

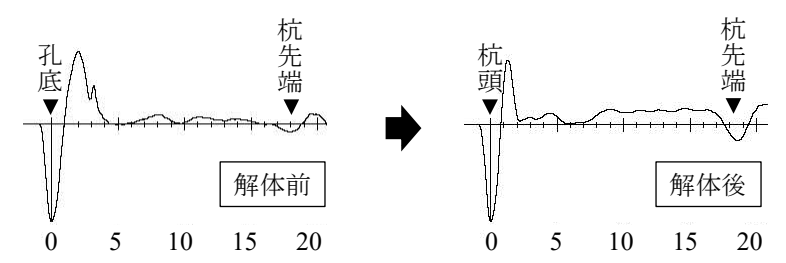

図 9 パイルキャップの圧砕解体前後の 弾性波探査試験波形（損傷が生じなかった杭）
よび図 9 に示す。試験を実施した杭 9 本のうち, 2 本で損傷が生じ たことを確認したが，ここでは，損傷が生じた杭と生じなかった杭 のうち, 代表的な 1 本の結果を示している。図 8 の圧砕解体後の波 形は, 杭頭打撃の山が崩れ, 杭先端反射も確認できないほど全体的 に大きく乱れていることから, この杭については, 解体により杭頭 近くに損傷が生じたと推察される。一方で, 図 9 の波形は, 解体後 も杭頭打撃と杭先端反射が明瞭で, その間に下向きに有意な振幅が 生じていないことから, この杭については, 解体により杭地中部に 損傷は生じなかったことを確認できる。さらに, 圧砕解体で損傷が 生じた図 8 の杭の孔内カメラ観察結果を図 10 に示す。図より, 解体 後の画像には, 深度 $0.5 \mathrm{~m}$ 位置に水平方向に幅 $1.0 \mathrm{~mm}$ のひび割れが新

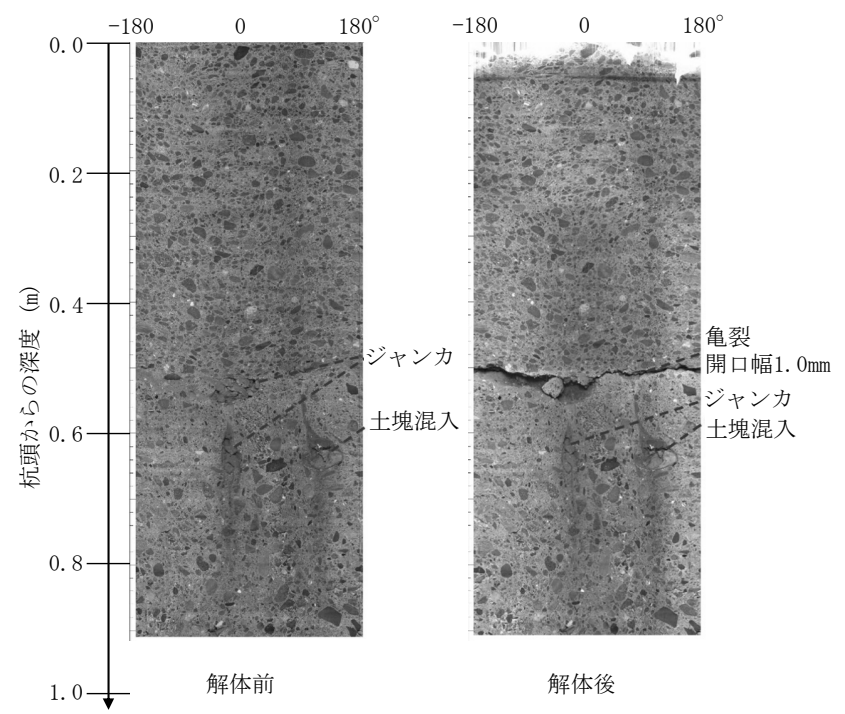

図 10 パイルキャップの圧砕解体前後の 孔内カメラ観察結果 (損傷が生じた杭)
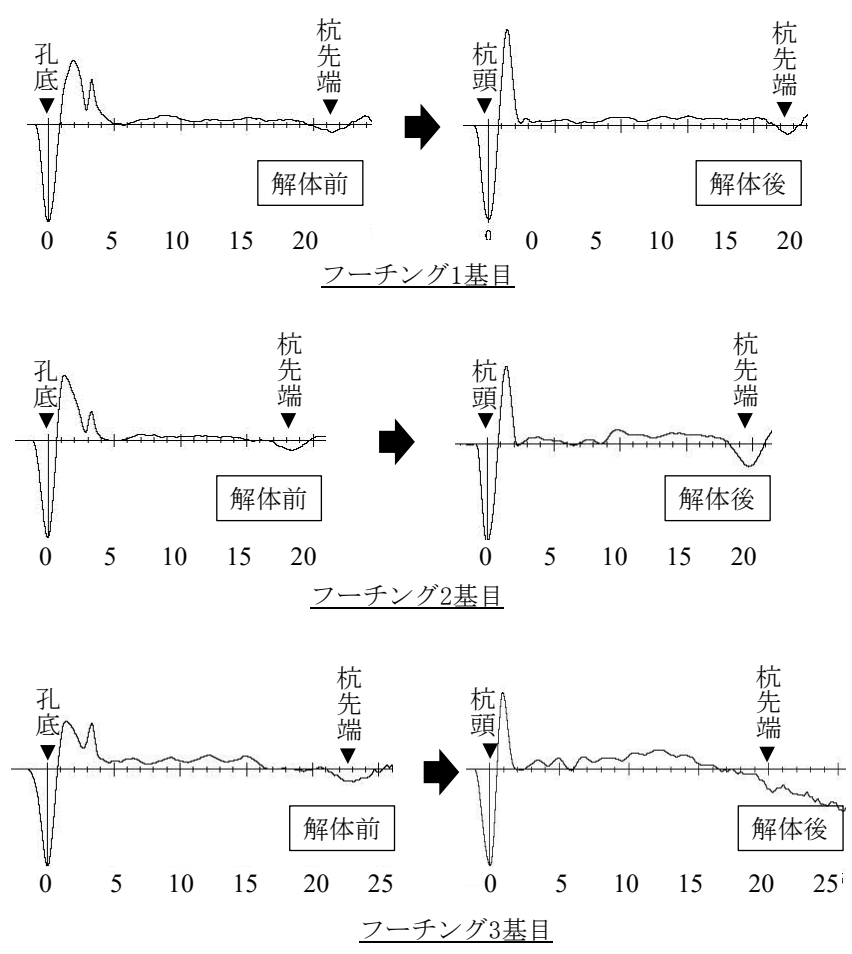

図 11 パイルキャップのカッター併用解体前後の弾性波探査試験波形 
たに生じており，前述した弾性波探查試験結果から推察された損傷 の傾向と一致する。ひび割れの状況から, ブレーカをパイルキャッ プ内に吒き入れ，こじるように破砕したことで水平力が作用し，曲 げひび割れが生じたと推察される。このように, 圧砕解体により杭 9 本のうち 2 本で損傷が生じたが, それぞれ異なるパイルキャップ に接合した杭であったことから，偶発的にある基礎の解体の仕方が 粗雑だったのではなく, パイルキャップの圧砕解体は杭を損傷させ る可能性が高いと判断した。

続いて, カッター併用解体とワイヤーソー併用解体について, 弾 性波探查試験で得られた波形を図 11 および図 12 に示す。どちらの 解体方法でも, 試験を実施した杭 9 本寸べてで損傷は確認されなか ったことから，ここでは，フーチングごとに代表的な 1 本の結果を 示している。図より, 圧确解体で損傷が生じなかった杭(図 9) と同 様の特徵を示しており, 解体により杭地中部に損傷は生じなかった ことを確認できる。また，ここでは結果を割愛したが，孔内カメラ 観察により, どちらの方法でも杭頭部に, 杭内部にまで進展するほ どの損傷は生じなかったことを確認している。以上より, 考案した カッター併用解体は, ワイヤーソー併用解体と比較して既存杭の健 全性への影響は同等であり, どちらの方法も杭を損傷させる可能性 は低いと考えられる。

さらに, 図 9,11,12 で示した損傷が生じなかった杭の弾性波探査 試験結果のうち, 杭の損傷評価に係る特徵以外について解体前後で 比較する。解体前は杭頭に設けた試験孔底において, 解体後は露出 した杭頭において，それぞれ打撃入力を行った影響が波形に現れて いる。解体前後どちらの波形にも, 深度 $1 \sim 2 \mathrm{~m}$ 位置に打撃入力のリ バウンドと思われる正側の振幅が生じているが，解体前の波形には さらに深度 3〜 $4 \mathrm{~m}$ 位置にも振幅が生じている。これは, 解体前はパ イルキャップがある状態で試験しており, 孔底で打撃入力した波が 杭先端以外にパイルキャップでも反射したためと考えられる。また, 解体後の波形の杭先端反射の深度は, 解体前に比べ $1 \mathrm{~m}$ 深くなってい るが,これは, 削孔して形成した試験孔底が杭頭より $1 \mathrm{~m}$ 深い位置に あるためである。以上より, 解体前後の弾性波探査試験波形の比較 を行い, 解体前の波形にはパイルキャップの存在や試験孔底での打 撃入力に起因する特徴が現れるが, 杭の損傷評価には影響しないこ とを示した。

\section{3 各解体方法の施工性比較}

各解体方法の施工性について, 解体に要した延べ人工と日数によ り比較し, 表 3 に示す。表中には，4.1〜4.2 節で述べた解体による 杭損傷度も併せて示している。地中梁について, 考案したカッター 併用解体に要する人工・日数は圧砕解体とほぼ変わらなかったが, これは, はじめに梁両端を切削してパイルキャップから切り離す工 程以外は, 圧砕解体と同一の工程であるためである。地中梁の解体 方法の選定にあたっては, どちらの方法も杭を損傷させないことか ら, 従来通り圧砕解体を採用寸る, あるいは, より安全側の判断で カッター併用解体を採用することも考えられる。

次に, パイルキャップの解体方法の選定にあたっては, 表 3 の通 り圧砕解体は最も施工性に優れた方法であるが，杭を損傷させる可 能性が高いため, 採用する場合は杭に近い部分は手斫りとする等, 慎重に計画する必要がある。ワイヤーソー併用解体は杭を損傷させ る可能性が低い方法ではあるが, 圧砕解体に比べ施工性が著しく低
下するため，採用する場合は工程に十分な余裕を持たせる必要があ る。考案したカッター併用解体については, 圧砕解体に比心゙施工性 は若干劣るものの, ワイヤーソー併用解体と同様に杭を損傷させる 可能性は低いことを考えると,バランスの取れた解体方法といえる。 なお, ここで示した結果は本実験条件における結果であり, 現場状 況により異なることに留意されたい。

\section{5. まとめ}

既存杭利用のための基礎解体方法について, 杭の健全性を損なわ ず施工性にも優れる方法の選定を目的として, 実建物の地中梁とパ イルキャップおよび杭を用いて実証実験を実施した。検討した解体 方法は, 圧砕機やブレーカを用いる施工性に優れた圧砕解体, 杭を 損傷させる可能性が低いワイヤーソー併用解体, および, それらの 特徵を併せ持つカッター併用解体である。

地中梁については, 圧砕解体とカッター併用解体は, 施工性や既 存杭の健全性への影響の点で同等であった。パイルキャップについ ては, ワイヤーソー併用解体と同様に既存杭の健全性一の影響は小
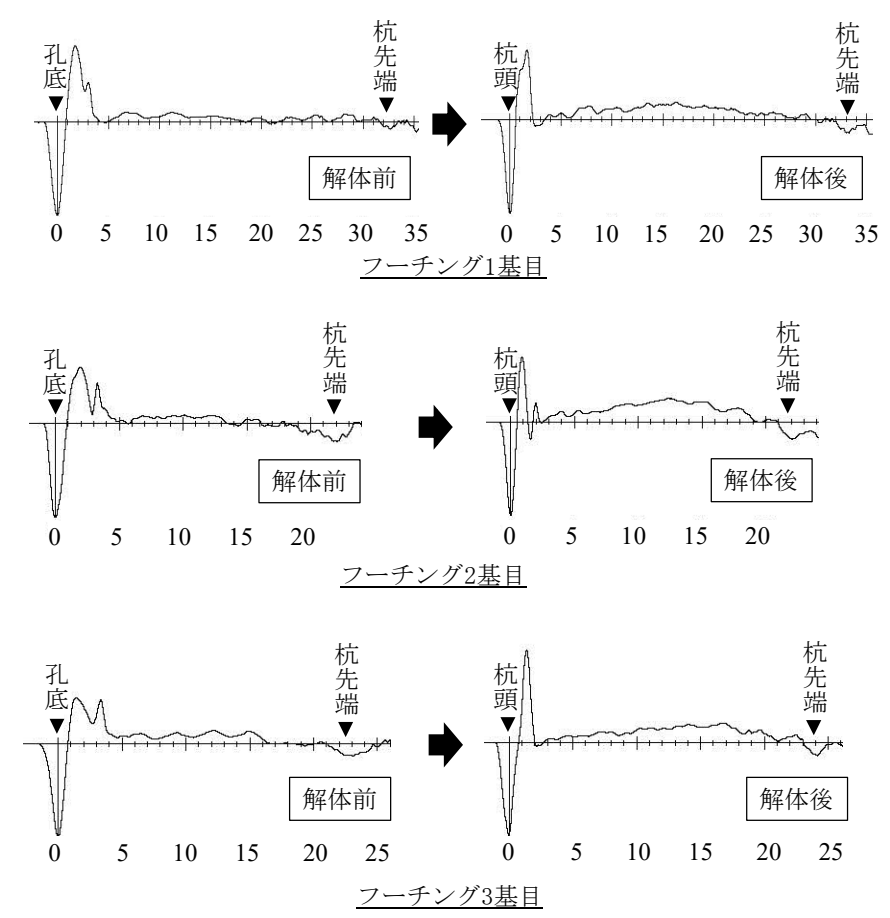

図12 パイルキャップのワイヤーソー併用解体前後の弾性波探査試験波形

表 3 検証した解体方法による杭損傷度および施工性の比較

\begin{tabular}{|c|c|c|c|c|c|}
\hline \multirow{2}{*}{ 部位 } & \multicolumn{2}{|c|}{ 解体方法 } & \multirow{2}{*}{$\begin{array}{c}\text { 既存杭の } \\
\text { 健全性への影響 } \\
\end{array}$} & \multicolumn{2}{|c|}{ 施工性 } \\
\hline & 名称 & 概要 & & 人工* & 日数* \\
\hline \multirow{2}{*}{ 地中梁 } & 圧砕解体 & 図 1 (a) & 杭 9 本すべて健全 & 1 & 1 \\
\hline & $\begin{array}{l}\text { カッター } \\
\text { 併用解体 }\end{array}$ & 図 1(b) & 杭 9 本すべて健全 & 1.5 & 1 \\
\hline \multirow{3}{*}{$\begin{array}{l}\text { パイル } \\
\text { キャップ }\end{array}$} & 圧砕解体 & 図 2 (a) & 杭 9 本中 2 本で損傷発生 & 1 & 1 \\
\hline & $\begin{array}{l}\text { カッター } \\
\text { 併用解体 }\end{array}$ & 図 2(b) & 杭 9 本すべて健全 & 1.5 & 2 \\
\hline & $\begin{array}{c}\text { ワイヤーソー } \\
\text { 併用解体 }\end{array}$ & 図 $2(\mathrm{c})$ & 杭 9 本すべて健全 & 7 & 10 \\
\hline
\end{tabular}

* 圧砕解体を 1 とした場合の值 
さいが, 施工性は圧确解体と大きく変わらないカッター併用解体が 最も合理的であることを確認した。

また, 既存杭利用にあたり建物解体前に杭の試験を実施する場合 もあるが，解体後に実施する試験とは方法が変わるため結果も異な る。本実験で得られた, 解体前後の弾性波探查試験波形の比較を行 い，解体前の波形にはパイルキャップの存在や杭体に設けた試験孔 底での打撃入力に起因する特徴が現れるが，杭の損傷評価には影響 しないことを示した。

最後に, 本実験を実施するにあたり, 多大な御協力を頂きました 工事事務所ならびに関係各位に心から謝意を表します。

\section{参考文献}

1)建設業協会：既存杭利用の手引き，2003. 2

2) 構造法令研究会 [編]：既存杭等再使用の設計マニュアル(案), 2008

3) 特集 まるごと「解体工事」NOW，建築技術 第 738 号, pp. 128～129, 2011.7

4) カッターホイール, 入手先〈http://www. erkat. de/ja/products/erw/〉, (2017/9/19 参照)

5) 監理技術者講習テキスト 2017 年度 第 1 版，p. 283，2017.6

[2018 年 1 月 4 日原稿受理 2018 年 5 月 24 日採用決定 $]$ 